\title{
STUDY OF HEPATOPROTECTIVE ACTIVITY OF ECBOLIUM VIRIDE (FORSSK.) ALSTON
}

\author{
J.JAYAPRAKASH NARAYANAN*, J. JANORIOUS WINKA, M. \\ RAJKUMAR \& KL. SENTHIL KUMAR \\ *Departments of Pharmacognosy, Padmavathi College of Pharmacy \& Research Institute, Periyanahalli,
} Dharmapuri - 635205, Tamil Nadu, India.

\begin{abstract}
Objective: To evaluate the hepatoprotective activity of ethanolic extract of Ecbolium viride (Forssk.) Alston in $\mathrm{C} \mathrm{Cl}_{4}$ induced rats.

Materials and Methods: The authenticated leaves of Ecbolium viride (E.V) were collected from ABS botanical garden, Salem, Tamil Nadu. The ethanol extract was tested for acute oral toxicity study by using OECD guidelines 423 . The starting dose level of Ethanolic extract of $E . V$ was $2000 \mathrm{mg} / \mathrm{kg}$. Body weight p.o. and the route of administration was oral. Dose volume was administered $0.1 \mathrm{ml} / 100$ gms body weight to the rats, which were fasted over night with water ad libitum. Assessment of hepatoprotective activity was carried out on albino wistar rats. The animals were segregated into five groups of six animals each.

Group I served as normal control receiving $5 \% \mathrm{CMC}(10 \mathrm{ml} / \mathrm{kg})$. All other groups received $\mathrm{CCL}_{4}(1 \mathrm{ml} / \mathrm{kg})$ with equal volume of olive oil $\left(50 \%\right.$ v/v) for two successive days. Group II animals were maintained as $\mathrm{CCL}_{4}$ group, while group III, IV and V animals were treated orally for seven days with suspension of extract $(100 \mathrm{mg} / \mathrm{kg})$, extract $(200 \mathrm{mg} / \mathrm{kg})$ and reference drug silymarin $(25 \mathrm{mg} / \mathrm{kg})$, respectively. After the drug treatment all the animals were sacrificed by cervical dislocation. Blood was collected from the carotid artery and was allowed to clot for 45 min at room temperature; serum was separated by centrifugation at $2500 \mathrm{rpm}$ for $15 \mathrm{~min}$, used for the estimation of various biochemical parameters namely GOT, GPT, ALP, ACP and Bilirubin. Biochemical parameters such as Serum Glutamate Pyruvate Transaminase (SGPT), Serum Glutamate Oxaloacetate Transaminase (SGOT), Serum Alkaline Phosphatase (SALP), Serum acid Phosphatase (SACP), Liver, and Bilirubin (total \& direct) were determined

Results: The acute oral toxicity studies showed that ethanolic extract of E.V up to $2000 \mathrm{mg} / \mathrm{kg}$ are non toxic and safe. This studies shows that ethanolic extract of $E . V$ possess good hepatoprotective activity. This hepatoprotective activity shown by the E.V may be possibly was due to the active constituent present in these extracts which was responsible for the pharmacological action.

Conclusion: The results indicates that ethanolic extract of EV leaves possesses significant hepat op otective activity.

Key words: Hepatoprotective, Silymarin, Ecbolium viride (Forssk.) Alston, Hepatotoxicity and Acute oral toxicity study.
\end{abstract}

\section{INTRODUCTION}

Hepatotoxicity: Damage or injury to the liver caused by a drug, chemical or other agent. Symptoms vary depending on the degree of exposure and hence extent of the liver damage or injury. Mild liver damage may cause few if any symptoms whereas severe damage can ultimately result in liver failure.

Herbal-based therapeutics for liver disorders has been in use in India for a long time and has been popularized world over by leading pharmaceuticals. A large number of plants and formulations have been claimed to have hepatoprotective activity. Nearly 160 phytoconstituents from 101 plants have been claimed to possess liver protecting activity.Therapies developed along the principles of allopathic medicine are often limited in efficacy, carry the risk of adverse effects, and are often too costly, especially for the developing country like India. Therefore, treating liver diseases with plant-derived compounds which are accessible and do not require laborious pharmaceutical synthesis seems highly attractive.

\section{Materials and Methods}

Collection and Authentication of Plant Material: The Ecbolium viride plant specimens for the proposed study were collected from ABS Botanical Gardens Salem, Tamil Nadu. Care was taken to select healthy plants.

Extraction: The leaves were dried under the shade and made to fine powder using a laboratory mill. The powdered plant material $(250 \mathrm{gm})$ was extracted with absolute ethanol using soxhlet apparatus for 24 hours. The solvent was then removed under reduced pressure and controlled temperature $\left(40-50^{\circ} \mathrm{C}\right)$. Finally, a dark brown colored crude extract was obtained (yield: $8.3 \%$ w/w). Similarly a aqueous extract also prepared using water. The yield obtained was $12.7 \% \mathrm{w} / \mathrm{w}$. The ethanolic extract was subjected to pharmacological studies. 
Preparation of Drug Solution: The ethanolic extract of leaves of Ecbolium viride (Forssk.) Alston were used for screening of hepatoprotective activity. Suspension of extract was prepared using 5\% Carboxy methyl cellulose (CMC) for hepatoprotective activity in $\mathrm{CCL}_{4}$ induced hepatotoxicity

Acute oral toxicity study: The OECD (Organization for Economic Co-operation and Development) guidelines No. 423. Wistar albino rats of either sex (180-220 g weight) were used.. Rats were kept for overnight fasting prior to drug administration. A total of three animals were used, which received a single oral dose $(2000 \mathrm{mg} / \mathrm{kg}$, body weight [b.w.]) of E.V ethanolic extract. After the administration of extract, food was withheld for further 3-4 hours. Animals were observed individually at least once during the first $30 \mathrm{~min}$ after dosing, periodically during the first 24 hours (with special attention during the first 4 hours), and daily thereafter for a period of 14 days. Once daily, cage side observations included changes in skin and fur, eyes and mucous membrane (nasal) and also respiratory rate, circulatory (heart rate and blood pressure), autonomic (salivation, lacrimation, perspiration, piloerection, urinary incontinence, and defecation) and central nervous system (drowsiness, gait, tremors, and convulsion) changes. Mortality, if any, was determined over a period of 2 weeks.

Experimental design: Assessment of hepatoprotective activity was carried out on albino wistar rats. The animals were segregated into five groups of six animals each. Group I served as normal control receiving 5\% CMC (10ml/ $\mathrm{kg})$. All other groups received $\mathrm{CCL}_{4}(1 \mathrm{ml} / \mathrm{kg})$ with equal volume of olive oil $(50 \% \mathrm{v} / \mathrm{v})$ for two successive days. Group II animals were maintained as $\mathrm{CCL}_{4}$ group, while group III, IV and V animals were treated orally for seven days with suspension of extract $(100 \mathrm{mg} / \mathrm{kg})$, extract $(200 \mathrm{mg} / \mathrm{kg})$ and reference drug silymarin $(25 \mathrm{mg} / \mathrm{kg})$, respectively. After the drug treatment all the animals were sacrificed by cervical dislocation. Blood was collected from the carotid artery and was allowed to clot for $45 \mathrm{~min}$ at room temperature; serum was separated by centrifugation at $2500 \mathrm{rpm}$ for $15 \mathrm{~min}$, used for the estimation of various biochemical parameters namely GOT, GPT, ALP, ACP and Bilirubin

Assessment of liver function: Biochemical parameters such as Serum Glutamate Pyruvate Transaminase (SGPT), Serum Glutamate Oxaloacetate Transaminase (SGOT), Serum Alkaline Phosphatase (SALP), Serum acid Phosphatase (SACP), Liver, and Bilirubin (total \& direct) were determined according to the methods described by Henry.

Estimation of serum glutamate pyruvate transaminase (SGPT): SGPT is also called Alanine Transaminase (ALT), which is located in cytosol of liver cell. During liver cell inflammation and break down of liver cells, they are released into circulation due to increased permeability of cell membrane. Hence determination of SGPT is an index of the extent of liver damage. Its normal serum level is 10-35 IU/L. Alanine amino transferase catalyses the transfer of amino group from alanine to $\alpha$ - keto glutarate $(\alpha-\mathrm{KG})$ with the formation of Glutamate and Pyruvate. The liberated Pyruvate reduced to lactate, by lactate dehydrogenase $(\mathrm{LDH})$ in the same reaction an equivalent amount of NADH is oxidized to NAD.

Estimation of serum glutamate oxaloacetate transaminase (SGOT): SGOT is located on the cytosol of liver. In addition, it is also found in the mitochondria and in many tissues of heart, liver, skeletal muscle and kidney. The hepatic cell damage leads to increased levels of SGOT in blood serum. Serum Glutamate Oxaloacetate Transaminase (SGOT) also known as Serum Aspartate Amino Transferase (AST) is a tissue enzyme that catalyses the exchange of amino and keto groups between alpha amino acids and alpha keto acids. AST is widely distributed in tissue principally cardiac, hepatic muscle and kidney; injury to these tissues results in increase in the AST (SGOT) enzyme level into general circulation. Hepatobilliary diseases, such as cirrhosis, metastatic carcinoma and viral hepatitis will also increases serum AST levels.

Estimation of serum alkaline phosphatase (ALP): Many tissues produce serum alkaline phosphatase, especially bone, liver, intestine and placenta and excreted in the bile. Most of the normal serum alkaline phosphatase (range 25-85 IU/dl) is derived from bone. Elevation in activity of this enzyme can be found in disease of bone, liver and in pregnancy. In the absence of bone diseases and pregnancy, an elevated serum alkaline phosphatase level generally reflects hepatobilliary disease. The greatest elevation (3-10 times normal) occurs in biliary tract obstruction. Slight to moderate increase is seen in parenchymal liver diseases such as in hepatitis and cirrhosis and in metastatic liver disease.

Estimation of (total and direct) bilirubin in blood serum: Bile is produced by liver, stored in the gall bladder and secreted via biliary ducts into duodenum. Bile consists of bile salts and bile pigments. To understand the mechanisms underlying biliary pathology, jaundice will develop if bilirubin is excessively produced, or there is impaired hepatic uptake and conjugation of bilirubin or it is insufficiently excreted into the duodenum. Tests are employed to assess the synthesis and elimination of bilirubin pigment.

Effect on liver weight: After collecting the blood from the biochemical parameter the livers were isolated, washed with alcohol and weight was determined by recording liver weight with respect to body weight per 100 gram. The isolated livers were preserved in $10 \%$ neutral formalin solution for histopathological studies. 
Results:

Effect of EV Ethanolic Extract on Acute Toxicity Study: Acute toxicity study revealed the non-toxic nature of the extract. There was no mortality or any toxic reactions found at the maximum tested dose level of $2000 \mathrm{mg} / \mathrm{kg}$.

Effect of EV Ethanolic Extract on CCL4 induced rats: This studies shows that ethanolic extract of E.V possess good hepatoprotective activity

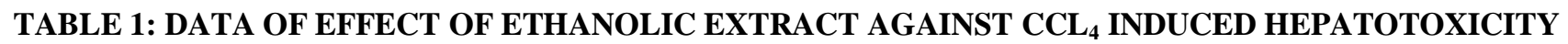
IN RATS

\begin{tabular}{|c|c|c|c|c|c|c|}
\hline \multirow[t]{2}{*}{ Treatment } & \multirow[t]{2}{*}{ AST (U/I) } & \multirow[t]{2}{*}{ ALT (U/I) } & \multirow[t]{2}{*}{ ALP (U/L) } & \multirow[t]{2}{*}{$\operatorname{ACP}(\mathbf{U} / L)$} & \multicolumn{2}{|c|}{$\begin{array}{l}\begin{array}{l}\text { Bilurubin } \\
\text { blood) }\end{array} \\
\text { (mg/100 } \mathrm{ml} \text { of }\end{array}$} \\
\hline & & & & & Direct & Total \\
\hline Normal & $\begin{array}{l}97.3 \pm \\
1.1801\end{array}$ & $35.08 \pm 0.211$ & $\begin{array}{l}15.92 \pm \\
0.7217\end{array}$ & $10.5 \pm 0.0643$ & $\begin{array}{l}0.24 \pm \\
0.0217\end{array}$ & $0.39 \pm 0.0410$ \\
\hline $\mathrm{CCL}_{4} 1 \mathrm{ml} / \mathrm{kg}$ i.p & $\begin{array}{l}189.6 \pm \\
1.6102\end{array}$ & $\begin{array}{l}132.73 \pm 1.66 \\
00\end{array}$ & $97.9 \pm 6.807$ & $33.1 \pm 1.0804$ & $\begin{array}{l}0.52 \pm \\
0.0402\end{array}$ & $0.87 \pm 0.0605$ \\
\hline $\begin{array}{l}\text { E.viride extract } \\
(100 \mathrm{mg} / \mathrm{kg})\end{array}$ & $\begin{array}{l}142.7 * * \pm 1.9 \\
203\end{array}$ & $\begin{array}{l}67.5^{* * \pm} \\
1.8702\end{array}$ & $\begin{array}{l}78.4 * \pm \\
5.3034\end{array}$ & $\begin{array}{l}18.4^{* \pm} \\
0.4803\end{array}$ & $\begin{array}{l}0.48 \pm \\
0.0306\end{array}$ & $0.74 * \pm 0.0507$ \\
\hline $\begin{array}{l}\text { E.viride extract } \\
(200 \mathrm{mg} / \mathrm{kg})\end{array}$ & $\begin{array}{l}112.9 * \pm \\
2.3423\end{array}$ & $\begin{array}{l}44.6^{* * \pm} \\
1.3825\end{array}$ & $\begin{array}{l}37.6^{* * \pm} \\
1.8701\end{array}$ & $\begin{array}{l}12.9 * \pm \\
0.1124\end{array}$ & $\begin{array}{l}0.33 * \pm 0.01 \\
50\end{array}$ & $0.45 * \pm 0.2106$ \\
\hline $\begin{array}{l}\text { Silymarin } \\
\mathrm{mg} / \mathrm{kg})\end{array}$ & $\begin{array}{l}105.4 * * \pm \\
2.307\end{array}$ & $\begin{array}{l}49.8^{* * \pm} \\
4.7003\end{array}$ & $\begin{array}{l}33.6^{* * \pm} \\
2.4031\end{array}$ & $\begin{array}{l}15.7 * \pm \\
0.9005\end{array}$ & $\begin{array}{l}0.18^{*} \pm 0.00 \\
81\end{array}$ & $0.23 * \pm 0.0105$ \\
\hline
\end{tabular}

Data are expressed as mean \pm SEM, $n=6$

$\mathrm{P}<0.01$ Vs Control, ** $\mathrm{P}<0.001$ Vs Control

Table 2: EFFECT OF EXTRACT OF ECBOLIUM VIRIDE ON SUPEROXIDE DISMUTASE, CATALASE \& GLUTATHIONE PEROXIDASE ON CCL 4 INDUCED RATS

\begin{tabular}{|c|c|c|c|}
\hline Treatment & ${ }_{-1}^{\text {SOD (mg liver protein) }}$ & $\begin{array}{l}\text { Catalase } \\
\text { protein }^{-1}\end{array} \quad$ (mg liver & $\begin{array}{l}\text { Glutathione Peroxidase } \\
{\text { (mg liver protein })^{-1}}^{-1}\end{array}$ \\
\hline Normal & $77.83 \pm 5.4002$ & $298.55 \pm 21.3015$ & $0.992 \pm 0.0504$ \\
\hline $\begin{array}{lll}\mathrm{CCL}_{4} & 1 \mathrm{ml} / \mathrm{kg} & \text { body } \\
\text { weight } & & \end{array}$ & $53.20 \pm 3.3032$ & $171.92 \pm 8.3012$ & $0.61 \pm 0.0304$ \\
\hline $\begin{array}{l}\text { E.viride extract } 100 \\
\mathrm{mg} / \mathrm{kg}\end{array}$ & $66.90 * \pm 6.5102$ & $263.7 * \pm 18.7502$ & $0.86^{*} \pm 0.0602$ \\
\hline $\begin{array}{l}\text { E.viride extract } 200 \\
\mathrm{mg} / \mathrm{kg}\end{array}$ & $77.8^{*} \pm 7.2120$ & $275.4 * \pm 16.2012$ & $0.93^{*} \pm 0.0801$ \\
\hline Silymarin ( 25 mg/kg) & $73.8^{*} \pm 7.1011$ & $267.3 * \pm 19.1203$ & $0.95^{*} \pm 0.0301$ \\
\hline
\end{tabular}


Table 3: EFFECT OF EXTRACT OF ECBOLIUM VIRIDE ON SERUM CHOLESTEROL, UREA,

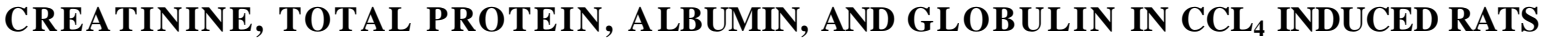

\begin{tabular}{|c|c|c|c|c|c|c|}
\hline Treatment & Cholesterol & $\begin{array}{l}\text { Urea (mg / } \\
\text { dl) }\end{array}$ & $\begin{array}{l}\text { Creatinine } \\
(\mathrm{mg} / \mathrm{dl})\end{array}$ & $\begin{array}{l}\text { Protein } \\
\text { (g/dl) }\end{array}$ & $\begin{array}{l}\text { Albumin } \\
\text { (g/dl) }\end{array}$ & $\begin{array}{l}\text { Globulin } \\
\text { (g/dl) }\end{array}$ \\
\hline Control (NaCl) & $79.58 \pm 6.27$ & $25.9 \pm 1.2$ & $0.73 \pm 0.04$ & $3.5 \pm 0.8$ & $2.4 \pm 0.3$ & $1.1 \pm 0.5$ \\
\hline $\begin{array}{l}\mathrm{CCL}_{4}-\text { Olive oil } \\
(3 \mathrm{ml} / \mathrm{kg})\end{array}$ & $98.63 \pm 5.6$ & $34.6 \pm 1.3$ & $0.74 \pm 0.13$ & 0.8 & 0.7 & $=0.1$ \\
\hline $\begin{array}{l}\text { E.viride extract } \\
(100 \mathrm{mg} / \mathrm{kg})\end{array}$ & $96.5 \pm 8.4$ & $33.7 \pm 0.3$ & $0.75 \pm 0.07$ & $4.2 \pm 0.4$ & $2.9 \pm 0.3$ & $1.3 \pm 0.1$ \\
\hline $\begin{array}{l}\text { E.viride extract } \\
(200 \mathrm{mg} / \mathrm{kg})\end{array}$ & $94.2 \pm 7.8$ & $31.8 \pm 2.9$ & $0.71 \pm 0.06$ & $3.6 \pm 0.3$ & $2.4 \pm 0.1$ & $1.2 \pm 0.2$ \\
\hline $\begin{array}{l}\text { Silymarin } \\
\mathrm{mg} / \mathrm{kg})\end{array}$ & $89.3 \pm 4.3$ & $30.13 \pm 1.9$ & $0.73 \pm 0.05$ & $2.8 \pm 0.5$ & $1.1 \pm 0.3$ & $1.7 \pm 0.2$ \\
\hline
\end{tabular}

Data are expressed Mean \pm SEM, $n=6$.

Table 4: EFFECT OF ECBOLIUM VIRIDE EXTRACT ON LIVER WEIGHT AGAINST CCL 4 INDUCED HEPATOTOXICITY IN ALBINO RATS

\begin{tabular}{|l|l|}
\hline Groups & Liver Weight $(\mathbf{g m})$ \\
\hline Normal Control $(\mathbf{1 0 m} / \mathbf{k g})$ & $7.12 \pm 0.55$ \\
\hline $\mathbf{C C L}_{4} \mathbf{1} \mathbf{m l} / \mathbf{~ k g}$ & $11.46 \pm 0.45$ \\
\hline E. Viride extract $(\mathbf{1 0 0} \mathbf{~} \mathbf{~ g ~} \mathbf{~ k g )}$ & $8.90 \pm 0.15$ \\
\hline E. Viride extract $(\mathbf{2 0 0} \mathbf{~} \mathbf{m g} / \mathbf{~ k g})$ & $7.72 \pm 0.28$ \\
\hline Silymarin $(\mathbf{2 5} \mathbf{m g} / \mathbf{~ k g})$ & $7.26 \pm 0.05$ \\
\hline
\end{tabular}

\section{Discussion:}

Alanine transaminase is present in high concentrations in liver, kidneys, heart and skeletal muscle tissue. It is also present in lung, spleen, pancreas, brain and Erthrocytes at a lower concentrations. Primary liver diseases (cirrhosis, obstructive jaundice, carcinoma, viral or toxic hepatitis) as well as liver damage secondary to other causes result in elevated GPT levels. Patients undergoing extended hemodialysis without (Rit-L) supplemental vitamin $\mathrm{B}_{6}$ therapy may show low GPT in serum. Aspartate transaminase is present in all human tissues of the body. It is also present in large amounts in liver, kidneys, heart and skeletal muscle. When any of these organs is damaged or diseased, serum GOT level rises. The rise is proportional to the extent of damage or disease. Elevated levels are associated with liver disease or damage, mycordial infarction, muscular dystrophy and cholecystitis. In myocardial infarction GOT/AST levels increase after 3 to 8 hours of onset of attack and returns to normal in 4 to 6 weeks.

The duration and extent of increase in level is proportional to the severity of attack. The change in levels over a period of time is useful to the physician in evaluating myocardial infarction, following chronic heart disease or resolving hepatitis.Alkaline Phosphatase is widely distributed throughout the body, but the clinically important once for diagnostic reason are in bone, liver, placenta \& intestine. Growing bone is associated with the release of AKP, \& so in childhood the level of AKP is around 3 times of that of adult.

During pregnancy in $2^{\text {nd }}$ and $3^{\text {rd }}$ trimester the enzyme rises considerably due to placental releasing AKP. It can be used to examine placental function. Elevated levels we seen in bone diseases, eg.Pagets disease, rickets, osteoblastic metastatic, \& in obstructive disease of billiary tract. Decreased levels are rarely seen eg. In vitamin A resistant rickets. Acid phosphatase is found in small amount in a number of tissues such as bones, kidneys, spleen and liver. Large amount of acid phosphatase is present in adult prostate tissues and in prostatic secretion. The prostatic acid phosphatase activity in serum is elevated in prostatic cancer. Hence, determination of serum acid phosphatase is vital in patients with suspected prostatic concer. In case of certain liver, bone diseases and excessive destruction of platelets, prostatic acid phosphatase activity is elevated. 
Increased levels of bilurubin are associated with biliary obstruction and hepatocellular diseases as well as hemolytic disorders in adults and new borns. Increased levels of direct bilirubin associated with biliary destruction and hepato cellular disease.

Conclusion: The acute oral toxicity studies followed by OECD guidelines -423 , fixed dose procedure, showed that ethanolic extract up to $2000 \mathrm{mg} / \mathrm{kg}$ are non toxic and safe. Ethanolic \& Aqueous extracts of Ecbolium viride (Forssk.) Alston showed significant anti microbial activity. The pharmacological studies of ethanolic extract showed significant hepatoprotective activity. It proved that active constituents present in these extracts may be responsible for this pharmacological action. The hepatoprotective activity of the plant Ecbolium virde has been further confirmed by biomedical parameters and histopathological studies.

\section{References:}

1. Ley JP et al., 2006, had isolated and synthesised a new unsaturated long chain 2-ketol ester from Ecbolium viride (Forssk.) Alston.

2. Mondal AK et al., 1998, had Analysed free amino acid content in pollen of four Asteraceae species of known allergenic activity including Ecbolium viride

3. Ramsewak RS et al., 1999, had isolated three Bioactive $\mathrm{N}$-isobutyl amides from the flower buds of Ecbolium viride.

4. Mondal AK et al., 1998, had Analysed free amino acid contents of nine medicinal plants containing antimicrobial property including Ecbolium viride

5. Banerjee $\mathrm{G}$, et al., 1998 has done the pharmacognostical studies in ten aromatic plants including Ecbolium viride

6. Casado $\mathrm{M}$ et al., 2009, had isolated two new alkamides from roots of Ecbolium viride

7. Ang Boon Haw and Chan Lai Keng, 2003, Micropropagation of Ecbolium viride., a bio-insecticide plant, through proliferation of multiple shoots, J.Appl.Hort., 5(2): 65-68, July-December.

8. Casado M, Ortega MG, Peralta M, Agnese AM, Cabrera JL.2009, Two new alkamides from roots of Acmella decumbens., Nat Prod Res. 23(14) pp 1298-303.

9. Dpacker, J., Slater, T. and Wilson, R., Reactions of the Carbon tetrachloride related peroxy free radical $\left(\mathrm{CCl}_{3} \mathrm{O}_{2}\right)$ with aminoacids, pulse radiolysis evidence. Life Sci., 1978, 23, 2617-20.

10. Dahah, H., Martman, S.P. and Weinhouse, S., Formation of Carbonyl chloride in Carbon tetrachloride metabolism by rat liver in vitro, Cancer Res., 1979, 39, 3942-47.

11. Dasto, J.A., Ferrya, G.C., Castro, C.R., Sasame, H., Fenos, O.M. and Gillete, J.R., Prevention of Carbon tetrachloride induced necrosis by inhibitors of drug metabolism., Biochem. Pharmacol., 1974, 23, 95-302.

12. Dash GK, Samanta A, Kanungo SK, Sahu SK, Sureh P, Ganpaty S. Hepatprotective Activity of Leaves of Abutilon indicum. Indian Journal of Natural Product. 2000; 16(2): 25-26.

13. Nadkarni's INDIAN MATERIA MEDICA Vol.-1, Popular Prakashan, pg.no.1163.

14. Divakar Madhu C.,Plant Drug Evaluation a laboratory guide, pg.120.

15. Easu,K. 1964, Plant anatomy, John Wiley and sons. New York.pg767.

16. Egon Stahl 1965, TLC a Laboratory hand book New York, pg. 252.

17. Furnis B.S., Hannaford. A.J., Rajesh V., suilap M.G. and Taichan A.R., 1994, "Vogels Text of Pratical Organic Chemistry" 8th edition published by longman group. p. 395-401.

18. Gamble, J.S 1935, Flora of the Presidency of Madras.Vol. I, II, III.Botanical Survey of India, Calcutta, India.

19. Divakar Madhu C 2006, Plant Drug Evaluation a laboratory guide, pg.120.

20. Gephardt 2002, “Oxidative stress, Plant Derived Antioxidants Liver Fibrosis, Planta Medica, 4(68), 289-296.

21. Ghosh M.N, "Fundamentals of Experimental Pharmacology" Scientific Book Agency, Calcutta, (1984), $156-157$.

22. Harbone, J.R., phytochemical methods, A guide to modern techniques of plant analysis, pg.4-8.

23. Harsh Mohan 1998, "Text book of Pathology", 3rd ed, Jaypee brothers, Medical Publishers Pvt. Ltd., 686-760.

24. Henry R.J 1960, American Journal of clinical pathology, 34,318. 